\title{
FAMILY-BASED CORRUPTION PREVENTION THROUGH PESANTREN VALUES
}

\author{
Samsul Arifin ${ }^{1}$, Moßhammad Baharun ${ }^{2}$, and Rahmat Saputra ${ }^{3}$ \\ ${ }^{1,2}$ Universitas Ibrahimy, Situbondo, Indonesia \\ ${ }^{3}$ Sultan Zainal Abidin University, Tarengganu, Malaysia \\ Email: syamsulahasan@ibrahimy.ac.id
}

Received: February 13, 2021

Accepted: April 25, 2021

\section{Abstract}

Pesantren (Islamic boarding school) has a great potential for family-based corruption prevention. This study aims to determine the values of pesantren and portraits of sakinah family personalities in the texts of "Zadu Az-Zaujayn" and "Syair Madura" in relation to corruption prevention. It uses an ethnographichermeneutic qualitative approach. The research concludes that the value of pesantren associated with the prevention of corruption lies in the expression "Mondhuk entar ngabdi bhen ngaji (the intention of going to pesantren is to learn and to serve)" and "Mon ngecok jerum e pondok mon mole ka romana ngecok jheren (if you steal a needle in pesantren, you will steal a horse once you get back home)". Through the values, students are accustomed to serving people and being careful of taking others' belongings. Meanwhile, the values of sakinah family within the text are wara' (being cautious and able to self-control), zuhud (living a simple life and prioritizing others' need), and patient (being tender and dare to face difficulties); qona'ah (accepting life as it is), ridha (accepting the provisions of God); and self-presentation. This research is vital to develop to achieve sakinah families free of corruption.

Pondok pesantren memiliki potensi besar dalam mencegah korupsi berbasis keluarga. Penelitian ini bertujuan untuk memaparkan nilai-nilai pesantren dan 
potret kepribadian keluarga sakinah dalam teks kitab "Zadu Az-Zaujayn" dan "Syair Madura" terkait pencegahan korupsi. Metode penelitian menggunakan pendekatan kualitatif tipe etnografi-hermeneutik. Hasil penelitian: nilai-nilai pesantren yang terkait dengan pencegahan korupsi yaitu "Mondhuk entar ngabdi dan ngaji (mondok untuk mengabdi dan mengaji)". Santri juga menghindari ngecok (mencuri): "Mon ngecok jerum e pondok mon mole ka romana ngecok jheren, (kalau mencuri sebuah jarum di pondok, pulangnya akan mencuri seekor kuda)". Dengan kedua nilai tersebut, santri akan terbiasa melayani orang lain dan menjauhi mengambil hak milik orang lain. Sedang kepribadian pasangan suami-istri sakinah yaitu mampu mengendalikan diri: yaitu wara' (hati-hati dan mampu mengendalikan diri), zuhud (hidup sederhana dan lebih mementingkan kepentingan orang lain), dan sabar (lapang dada dan berani menghadapi kesulitan-kesulitan); penerimaan hidup apa adanya: qona'ah (menerima kenyataan yang ada), ridha (ketenangan hati menerima ketentuan-ketentuan dari Allah); dan presentasi diri. Penelitian ini penting untuk dikembangkan, agar tercipta keluarga sakinah yang bebas dari korupsi.

Keywords: corruption; sakinah family; pesantren values

\section{Introduction}

Pesantren should participate in preventing corruption because, according to pesantrens and Nahdhatul Ulama, it belongs to tasharruf or ghulul (betrayal of trust) that can harm people financially, morally, and socially. Some corruption elements are extremely close to property crimes, which are known for; sariqah (theft), risywah (bribe), ghulul (embezzlement of public property), and hirabah (any action of damaging public order). Corruption violates the law, and it is a form of betrayal of the people's mandate (Muzadi, 2006).

Pesantrens are also increasing every year. In 2009/2010, there are 25,785 pesantren around Indonesia (Setjitden Pendidikan Islam Kemenag RI, 2010). Also, it plays as an educational and social institution that teaches religious values (tafaqquh fiddien). As a social institution, it is responsible for controlling the surrounding social life, including but not limited to corruption prevention (Arifin, 2018).

Pesantren teaches almost all aspects of life (from the ethic of washing to trading). Thus, the study program is a process of immersing an absolute value. The values created daily are then popular as "the life of santri" (Wahid, 2007). Pesantren is rich in values in relation to corruption prevention, such as what lies in the expression "Mon ngecok jerum e pondok, mon mole ka romana 
ngecok jheren" which means "if we steal a needle in pesantren, we will steal a horse when returning home". This expression teaches santri not to steal one's stuff for fear of being the real thief once back home. Almost all pesantren implement sanctions to repatriate santri who have been proven to steal (Ibrahimy \& Arifin, 2019).

Pesantren also has a great potential for family-based corruption prevention as it teaches several books about a good family management. For example, Pondok Pesantren Salafiyah Syafi'iyah Sukorejo Situbondo teaches Zadu AzZaujayn for the students who will get married. Zadu Az-Zaujayn is a book about reaching sakinah family by Nyai Zainiyah As'ad, Sukorejo. Sakinah family means a calm and peaceful family physically and spiritually. Families spare some evils and immoralities, including corruption (Arifin, 2019; Ibrahimy $\&$ Arifin, 2019).

Meanwhile, Syair Madura (Madurese Poetry) contains advice for young Madurese. It is the work of KHR. As'ad Syamsul Arifin, which consists of 232 lines. It was written in Ramadan around 1922 (Arifin, 1992). It emphasizes more on the description of ideal personalities in choosing a wife/husband to be. They will be manifested in everyday life and lead to sakinah family, which is safe, peaceful, orderly, neat, and diligent. The relationships with family members and neighbors are good, and all problems are well-addressed (Arifin \& Zaini, 2021; Arifin et al., 2021; Ibrahimy \& Arifin, 2018).

Teaching Zadu Az-Zaujayn and Syair Madura is basically a marriage counseling driven from uncommon local wisdoms. Some researches on marriage counseling have been so far about the importance and concepts of marriage counseling. No study explores the personality portraits of the wife/husband to be. Psychologically, personality, including corruption behavior, has a great influence towards a couple in making decision to choose a partner. Moreover, some corruptors have lately involved their family members. At the end of 2016, there were nine cases involving families. Some cases are committed by husband and wife, and some are by brothers and sisters (Angraeni, 2016). Therefore, studies on family-based corruption prevention are essential.

Studies on family-based corruption prevention from social traditions are prominent. So far, the dominant discourse and anti-corruption practices have experienced gaps with daily practices among societies. The discourse brought by the government and anti-corruption activists through the narrative of morality is global. Therefore, a research on local wisdom about the morality of corruption prevention and eradication is needed (Pertiwi, 2019). Besides, 
narratives about spirituality and morality must be internalized into values that may lead officials to avoid corruption (Sahama et al., 2019; Zaini \& Arifin, 2018).

This study aims to examine the values of pesantren associated with corruption prevention and to find out the characters of the sakinah family's personality in the texts studied by students, especially those found in Zadu Az-Zaujayn and Syair Madura related to corruption prevention. The theoretical framework of this study uses the perspective of indigenous counseling theory. Indigenous counseling presents a contextual approach (family, social, cultural, and ecological context) content (meaning, values, and beliefs) explicitly incorporated into the research design. Indigenous psychology is a scientific study of natural human behavior or thoughts that are not transported from other regions and are designed for the people. Thus, indigenous counseling advocates to examine the knowledge, skills, and beliefs that people have about themselves and examines these aspects in their natural context (Kim, 2006; Alwood, 2019).

The researchers also use pesantren-based counseling called at-tawazun counseling. A counseling with at-tawazun approach uses a balanced approach of various elements and oriented to the benefit. It helps the counselee manage anger, which always leads to bad deeds, to become khaira ummah who always invites good and prevents badness with great faith in God (Arifin \& Munfaridah, 2018).

In addition, this study uses the perspective of marriage counseling as it deals with married couples. Marriage counseling is organized as an educational method to reduce emotional tension, to help couples solve problems, and to discover better patterns of problem-solving (Riyadi, 2013). It builds and changes the mindset, attitude, willingness, and behavior of a couple or future husband and wife. The focus of marriage counseling is to generate a system of solving premarital and marital problems.

Culture-based prevention is prominent. Collectivity has a positive predictive correlation with the tendency to avoid corruption. Thus, the collectivity of every group, as a solid moral identity, needs to develope to prevent corruption in Indonesia (Abraham et al., 2014; Arifin, 2018).

A culture and environment of corruption also produce corrupt entrepreneurs. Successful rulers in a corrupt environment will tend to be authoritarian, cunning, and communicative. They create a business model that exploits all resources (Shurkina et al., 2013). It will endanger people's 
lives. When government are arrested, and the corrupt businessmen have no more connections, they no longer have a competitive advantage (Liu, 2016). Therefore, governments and civil society organizations should work together to eradicate corruption (Ngendakuriyo \& Zaccour, 2017). Also, it is done through the education involving media and culture, for example through the development of storybooks and the use of information technology (Nordin et al., 2012; Nurinten \& Mulyani, 2018; Pramanta et al., 2016).

Research on corruption prevention with Minangkabau and Lampung cultural approaches was carried out by Kurniawan (2019). To avoid a money politic, which is a part of corruption, people in Minangkabau have the principle of "adat basandi syarak, syarak basandi kitabullah (religious-based tradition, a religion based on the book of God"). Besides, people in Lampung uphold the moral order called piil pesenggiri. Both local wisdoms play as shields in preventing money politics (Kurniawan \& Hermawan, 2009). The study of local wisdom to prevent corruption is also to compensate for bribery and gratification as a fair gift from the social consensus. The issue-contingent model theory states that social agreement on an issue determines how it is considered ethical or unethical. When a bribery and gratification reap a common agreement, the community will judge that unethical acts are ethical (Mapuasari \& Mahmudah, 2018).

\section{Methods}

This research uses a qualitative research method for an ethnographichermeneutic type. An ethnographic approach is employed to assess pesantren values related to corruption prevention while hermeneutic aims to examine texts related to the personality of a married couple in the Zadu Az-Zaujayn and Syair Madura under a marriage counseling perspective. It adopt Gadamer's hermeneutics (Gadamer, 2004). The steps of this research are collecting texts and sourcebooks, making pre-interpretation, and conducting historical exposures.

\section{Results and Discussion}

\section{The values of "Ngabdi" and the Bad Effect of "Ngecok"}

The value of ngabdi, khidmah, or serving others is provided in the main teachings of pesantren. In serving a santri, one must perform wholeheartedly and avoid ngecok or stealing other people's belongings. If a santri steals one's 
stuff in a pesantren, they believe they will get plagues and their lives will not be blessed (Ibrahimy \& Arifin, 2018).

For pondok pesantren, serving others is a path that students must take in obtaining blessed knowledge (Abdusshomad, 2018). Pondok Sukorejo is popular with the motto "Mondhuk entar ngabdi dan ngaji (going to pesantren is for serving and learning)". We are willing to serve kiai, religious teachers, fellow students, and others to study religious knowledge.

According to Kiai Azaim (the scholar of pesantren), serving must be prioritized over science. It does not mean that science is less important, yet it will be easily gained through serving or devotion. Devotion will also lead to blessed and useful knowledge. According to Kiai Azaim, Pondok Sukorejo becomes a great pesantren because of the devotion of the founders; Kiai Syamsul and Kiai As'ad in serving students (Ibrahimy \& Arifin, 2018, 2019). Thus, both teacher and student have similar responsibility of devotion to serve. The only difference lies in the duty and obligation. Both must have an attitude in serving. The teacher must serve the student, and the student must also serve the teacher. Even, the scholar usually called himself as khadimul ma'had (boarding school servants) (Hasan, 2003).

Pesantren believes that devotion to teachers will lead to the mastery knowledge. Pesantren believes that the students must be diligent in learning and devoted to the teachers to get useful knowledge and blessings. The knowledge is the dream and hope of every santri interpreted as the following:

Barokah means more value than the material. Barokah refers to one's limited material, and it brings about kindness that prevents the owner to be insulted before God and man. Barokah is jawami' al-khair (the coffers of goodness), which is the number of favors from Allah SWT, so it brings happiness to live in the world and the hereafter .... Barokah in science is when a person's knowledge increases and s/he can practice it and spread it to others and bring him/her closer to Allah SWT. (Abdusshomad, 2018).

Ngabdi refers to serving others that can lead to ta'zhim (honor), respect, and care. For pondok pesantren, this character not only applies to students but also serves as a courtesy for teachers. Ta'zhim is not only seen through the physical attitude but also the inner aspects. For students, ta'zhim and devotion must be taken to obtain blessed knowledge.

When the students return home and become public officials, the job can be a means of worship and even deliver them to the God's pleasure and happiness in the hereafter. Thus, Kiai Afifuddin said: Good deeds should be prioritized by holders of public office, making policies that benefit people; 
fighting for prosperity, welfare, and justice, creating a safe, peaceful, and conducive atmosphere to prepare for the hereafter. With mediocre rituals, without tahajjud, dhuha, fasting on Monday and Thursday, and holding the Istighatsah Kubra in a grave houses or another palace, officials can easily go to heaven and get God's blessing as long as he carries out the public mandate as well as possible. Rasulullah SAW. said, "a day of a fair leader is better than sixty years of worship." (Arifin, 2020)

This model of behavior changes, emphasizes mental testing and experience. It follows the models of character formation applied by ancient Sufi sheikhs. They tested someone who wanted to enter a congregation for three years. In the first year, the prospective student was told to serve the community. In the second year, he was told to serve God and in the final year to watch over his heart. If he passed through, he could enter the tarekat and deserve to use murraqqa'ah, a symbol of true mystics. The prospective student could serve the community well if he positioned himself as indiscriminately a public servant (Al-Hujwiri, 2003).

Ngabdi is similar to the concept of unconditional positive regard in person-centered counseling. Unconditional positive regard is also referred to as acceptance, respect, or prizing. It involves the emphasis on respecting the counselee as a person or organism whose thoughts, feelings, beliefs, and whole self are openly accepted, without any conditions. Ngabdi is similar to the concept of altruism in psychoanalysis. Altruism includes mature defenses when someone gets inner satisfaction by serving others (Arifin, 2020).

The devoted attitude embedded in the hearts of the students and religious teachers of pesantren is one of the explanations why they still enjoy teaching at pesantren to help the Kiai. Even though they are given less honorarium, or even no honorarium at all. In addition to devotion, pondok pesantren is also known for being careful of controlling selves, so we are qualified to kiai. Santri is strictly forbidden to steal. Pesantren holds a jargon, "mon ngecok jerum e pondok mon mole ka romana ngecok jheren" (if we steal a needle in pesantren, we will steal a horse once we return home). A bad action in pesantren will cause fatal in later life.

Therefore, the values of serving and avoiding stealing other's belongings in pesantren are highly prominent in preventing corruption. Serving people wholeheartedly will never lead to corruption. By avoiding and fearing the bad effect, people will not corrupt, and they will live in blessings and happiness. 


\section{Personality Quality is the Foundation of the Sakinah Family}

Pondok Pesantren Salafiyah Syafi'iyah Sukorejo Situbondo teaches two interesting books relevant to marriage counseling. The first book is Syair Madura by KHR. As'ad Syamsul Arifin (1897-1990). This book contains poems of advice for young people who speak Madura and Arabic-Pegon letters. The second book is Zadu Az-Zaujayn written by Nyai Zainiyah As'ad (1944-2005). It is taught to students who will get married (Hasan, 2003; Ibrahimy \& Arifin, 2019).

The personality of the husband and wife defines sakinah family, which also functions as a corruption prevention. It includes:

\section{Capability of Making a Self-Control: Wara', Zuhud, and Patient}

There are three characters in the texts of the Syair Madura and Zadu Az-Zaujayn, which are related to the ability of a married couples to control themselves. They are very important to deal with family problems, including avoiding corruption.

Kiai As'ad describes female santri, the ideal wife, as:

Bejheng ngajina waro' tengkanah,

cokop elmonah raje himmanah

(Studying diligently, behaving wara',

adequate knowledge, great advantage)

(Arifin, 1992)

A husband must also have the same personality. He must be careful in supporting his wife. He does not give her money from forbidden work, including corruption, so the wife is safe. Nyai Zai illustrates:

Ya Allah dzul jalali wal ikrom, kami di dunia tak dihiraukan

Ilmu yang benar diajarkan, kini celaka kami rasakan

Kami diberi makanan haram, sandang dan pangan semua haram

Hati-hatilah jadi suami, apa yang wajib terhadap istri

Dhahir dan batin wajib nafkahnya, terhadap istri jangan tinggalkan

Tempat tinggalnya disediakan, walaupun sewa atau pinjaman

Yakni tak wajib memilikkannya, dan wajib pula beri khadamnya

(O Allah Dhul jalali wal ikrom, we in the world are ignored

True knowledge is taught, now we feel bad

We were given unclean food, clothing and food all unclean

Be careful of being a husband, what is required of a wife

Dhahir and batin support is in the world a must, so do not leave her 
The place of residence is provided, even if it is rent or loan

You are not required to give it, yet you must grant the khidmat) (As'ad, 1992)

Another personality which a married couple should have is patience. According to Nyai Zai, a married couple must possess patience so that the family can survive. If we are patient with our partner, our lives will be glorious. Nyai Zai quoted a hadith, "Whoever is patient on the bad deeds of his wife's morals, Allah will reward him as the reward given to the Prophet for being patient for his calamity. As for a wife who is patient with the bad deeds of her husband, Allah rewards her like the reward of those who die in wars upholding the religion of God".

Nyai Zai suggests to be patient and holding on to the pain, not telling our partner's weaknesses to others. The husband and wife must complement each other and cover the weaknesses. Allah says in Al-Baqarah: 187, "They (wives) are clothes for you (husbands) and you (wives) are clothes for them (wives)". If a wife is patient with her husband, she will rank like Siti Asiyah and Maryam.

Bila suami berwatak kejam, hanya menangis pedih dipendam

Di dalam surga dapat khasiat, pangkat sepadan Siti Asiyah

Dianiaya Fir'aun suaminya, serta dicincang tangan kakinya

Lalu dipukul batu yang besar, imannya tetap beserta sabar

Dia pemimpin para wanita, yang sama patuh pada suaminya

Tersebut pula Maryam namanya, di dalam surga pemimpin wanita

(If the husband is cruel, cry and bury your suffer

In heaven, you gain the benefit, a rank equivalent to Siti Asiyah

Persecuted by her husband, Fir'aun, as well as her legs are chopped

Then, she was hit with a large stone, her faith remains with patience

She is the leader of women, who is also obedient to her husband

Maryam, her name is also mentioned, in paradise she is the female leader)

(As'ad, 1992)

The characters of wara', zuhud, and sabar need to be possessed by a married couple. Wara' refers to being cautious by leaving doubtful (syubhat) and things not useful. It is the stability of the heart, when somebody is passionate about doing an action, so s/he can distinguish the right and wrong. It means leaving something doubtful and choosing the undoubtful one (Al-Muhasibi, 2001). Wara' is the beginning of zuhud. A person who is zuhud will not feel 
proud of the world's pleasures and will never complain because of losing his/ her belongings.

Wara' and zuhud are included in maqam or stages of the path that must be passed by a Sufi (Al-Qusyairi, 1998). According to Al-Muhasibi, people who are zuhud will leave lust, cleanse themselves from the dangers of lust, invite the soul to do what science advises, don't like to relax, and increase the ethos in good deeds (Al-Muhasibi, 2001; Al-Qusyairi, 1998).

Meanwhile, according to Shaykh Abdullah bin Alawi Al-Haddad, in terms of batiniyah, the essence of zuhud is to rid the world of the mind and erase it from the bottom of the heart. In his view, problems in the world seem very small (Al-Haddad, 2005). Wara', zuhud, and sabar contain moral values which teach to avoid corruption. People who have the values will avoid corruption because they will always control themselves and be careful by leaving something doubtful (syubhat) and less valuable. Zuhud means simple life and more concern on the interests of others. The essence of zuhud is eliminating worldly values, feeling enchanted towards it, and freeing the soul from the gratification of desires and pride. Patient can also prevent corruption acts. It is an attitude of grace and courage to face difficulties, to always show a rich attitude by hiding poverty in their life, and to behave well. Thorough patience, they will reach maturity. They have the resilience to suffering without complaining and demonstrate humanity that can tame anger and lust (An-Najar, 2001; Arifin, 2020; Shafii, 2004).

\section{Acceptance of Life as It is: Qona'ah, Ridha, and Ikhlas}

A married couple should have a personality of accepting life as it is, such as qona'ah (accepting the reality), ridha (accepting the provisions of Allah wholeheartedly) and ikhlas (cleansing and purifying the heart from other than Allah). The three characters are important for a couple to serve a family and to face life problems.

Kiai As'ad describes that the ideal married couple should be simple; neatly-dressed and sincere.

Nganggui pakaian ngalak bedhenah,

tadhe' pokallah bhen saderhana

Wakto ajelen tertib tengkanah,

rapi ben berse ikhlas atenah

(Wear the clothes as they are,

no show off and simple

Walking, she has an orderly step,

el Harakah Jurnal Budaya Islam Vol. 23 No. 1 Tahun 2021 
Her heart is neat and clean)

(Arifin, 1992)

Nyai Zai suggests to intend to worship once serving the husband:

Niat ibadah bagi si istri, pahala besar sudahlah pasti

Jikalah ridha ikhlas hatinya, tahulah istri ke urusannya

Walau bukanlah kewajibannya, hanya menambah amal baktinya

(When the wife intends for worship, she obviously gain a great reward.

If she is sincere, she must know her responsibility

Although it is not an obligation, she only does it for devotion)

(As'ad, 1992)

Ridha is the peace of heart to accept the provisions of God. He will not complain about the bitter fate. He accepts reality, gifts, and provisions from God (nrima ing pandum). Ridha usually comes from qonaah. Qonaah is accepting the reality. People who are qonaah will stay away from delusion and consider what happens in the future. It is related to psychiatric and self-concept. One will feel rich even if s/he is starving physically. S/he always helps others even though his/her wealth is negligible. S/he is rich in heart, not greedy. The soul feels free from suffering and delusion that will never happen (Al-Qusyairi, 1998).

Pleasure means eliminating hatred against the God's provisions that will or have occurred (qadha and qadr of Allah) and always living life with fun even though the reality is disasterous. S/he does it after trying hard and surrenders fully to God (tawakkal). Rida does not mean leaving the natural law (sunnatullah), but s/he must try hard and pray to God (Suhrawardi, 1998).

Ridha is categorized into three kinds: 1) being pleased with bitter experience for love (mahabbah) in God. Such love can eliminate the bitter feeling; 2), being pleased with the willingness to endure any sufferings. This is like drinking bitter herbs for curing acute diseases; 3 ) being happy because of the belief that God will grant a happy return behind the bitterness (Al-Ghazali, 2000).

Ikhlas is an act of cleansing and purifying the heart of something other than Allah. Those who are ikhlas will act no difference when receiving praise and scolding, not look at their work, and not demand a merit (Al-Qusyairi, 1998). Ikhlas has three pillars. The first pillar as a sincere foundation is intention. Intentions are motivations that drive abilities from knowledge. Knowledge raises motivation, and motivation raises ability, then the ability to help motivation moves the members of the body to do something. The second is the ikhlas of intention, which is pure motivation. The third is honesty, which is the perfection of ikhlas (Al-Ghazali, 2000). 
Qonaah, ridha and ikhlas are psychologically accepting life as it is. The manifestation of the three characters brings one's soul calm, peaceful, loving, empathetic, humble, and sincere. S/he will feel trustworthy, secure, and free from all desires and false hopes, including the desire to live in dissipation and corrupt behavior.

\section{Self-presentation}

Married couples (or married couple to be) must always create a good impression of their partners; both through appearance, speech, or other attitudes. This character, in social psychology, is known as self-presentation. Self-presentation is an effort made deliberately to act in a certain way that creates a special impression about yourself (Bordens \& Horowitz, 2008; Shelley et al., 2003).

The first manifestation of self-representation is maintaining appearance. A married couple must maintain their appearance before their partners. Ibn Abbas once said, "I like to dress up for my wife, as she likes to dress up for me". The Prophet Muhammad SAW said, "The best woman is that who if you look at her, she pleases you, if you command her, she obeys you, and if you stay away, she keeps her property and herself" (As'ad, 1992).

According to Kiai As'ad, a married couple should maintain their appearance, for example, wearing simple but clean, neat, and pure clothes. She is calm, rarely speak, always smile, and appear sweet. He said:

Berse tor suci angghui bhedennah,

berse bhen rapi roma tangganah

Panika putri raddin atenah, panika kufu' padhe santrenah (Her body and clothes are clean, Her family is clean and neat She has a beautiful heart, She is santri)

Potre kakdintoh ayem tengkanah, angghuiah sangat saderhanah Tadhe' ghejek rang rang dhebunah ghellekna mesem manis dhebunah (This girl is calm, her clothes are very simple No joking, rarely talking, laughing sweet at her words) 
(Arifin, 1992)

Nyai Zai said, a wife must be obedient to her husband and beaming face. A wife should not be surly.

Para wanita tiap harinya, haruslah taat ke suaminya

Berseri-seri wajah mukanya, menghadap suami tiap tingkahnya

Bermuka masam pada suami, inilah istri yang dimurkai

Murka Allah dan malaikat, akan terpukul yang tidak tobat

Women must obey their husbands every day

Their faces are bright, following their husband in every attitude

Being surly to the husband is enraged

The wrath of God and angels is unrepent hurt

(As'ad, 1992)

Kiai As'ad also hopes that we avoid couples who always live in hedonism, makeup, and tacky clothes, and those who like walking around and shopping.

Sifat panika nyu'un jeunah, mandher luputtah ce' tak terronah

Sangat tak hajat tekka deddinah, sangat bahaya dhe' kapotonah

Ngaksi malolo rajeh bandanah, nyalajeh ngator kembeng beddhe'na Nyalajeh ngator samper jingiknah, nyalajeh anggui sareng lipennah

Ngajek ngalencer tadhe' ambunah, lebur kapasar tadhe' busennah

(These characters are suggested to keep away, avoid it as it is badly unwanted Very unexpected until it happens, very dangerous to the grandchilds Showing off costs a lot, the makeup is too thick and one-sided The nip is also one-sided, the clothes and lipstick do not match Inviting to travel around always like going to market without boredom) (Arifin, 1992)

The second form of self-representation is keeping the words. A married couple must always keep his/her words to the partner. Nyai Zai writes, every 
couple should not say bad, make something that the partner dislikes, and s/ he may not say, "may God make you ugly" (As'ad, 1992). According to Kiai As'ad, a husband and wife must have smooth words, sweet words must be able to distinguish rough and fine language.

Cacanah alos tadhe' kasaknah, saling atanya asal molanah

Wakto akompol sareng kancanah, orengah ayem tadhe' gejeknah Cokop sem mesem tadhe' gelleknah, rang-rang cacanah manis dhebunah

Putri parabhen sopan tengkanah, begus akhlakkah muljeh budinah Dhebu se alos kasar basanah, oning bidhenah mabhe tengginah

Bhidenah mator dhe' sasepona bhidenah caca padhe ngodenah

(His/her words are subtle with no sound, asking each other at first

When hanging out with friends, $\mathrm{s} /$ he is quiet with no joke Smiling with no laugh, speaking a little unless expressing sweet words

The girl is polite, morally good and noble

Her words are soft, knowing the difference between high and low intonation Knowing how to talk to the elderly, and to the others in her age)

(Arifin, 1992)

The third self-representation is maintaining attitude. According to Nyai Zai, a wife must always be obedient to the husband, but the husband should not treat her like a slave.

Wajiblah taat pada suami/dalam istimta' harus pahami Jangan istrinya jadikan budak/dipaksa kerja atau memasak Itu semua atau lainnya/tidaklah wajib bagi istrinya Hati-hatilah kaum wanita/tiap menghadapi suaminya

Kalau tak untung di dunia ruwet/dan di akhirat nan lebih sangat 
A wife is supposed to obedient to husband/she must listen and understand Don't make his wife a slave/forced to work or cook

All or the others/are not mandatory for the wife Be careful, o women/once treating your husband

If you are not lucky, you will be complicated in the world/and will be more complicated in the hereafter

(As'ad, 1992)

According to Kiai As'ad, a family should hold: love affection, sweet smile, glowing face, using fragrance, and not dirty:

Lebur bhen eman dhe' kalakenah, padhe sem-mesem saking bungana (In love with her husband, smiling for being awfully pleased)

Terro paraben raddin atenah, begus akhlakkah tengka lakonah (Loving a girl with a beautiful heart, good moral and behavior)

Sedheng rajenah sedhe' tengkanah, badanna sing sing terak cahyanah (She is ideally mature with a good behavior Her body shines light) Berse bhen soce wajib ngartinah, sunnat hukumah ro'om bheunnah Cellakna mata pacar kokonah, manis matanah tanang duwaknah Manussa odhik bedhe bheunnah, oreng se jebbeh jubek robenah (Her body is clean and she understands what she should do, recommended to smell good The woe to the eyes and the nails, the eyes and two hands are sweet The living human smells bad, dirty and apparently ugly) (Arifin, 1992)

The focus of marriage counseling of pesantren is personality improvement and development of the prospective married couples because if they have a 
good personality, the problems in a marriage can be solved. They will avoid despicable acts; like corruption.

This research is in line with pesantren-based counseling research, at-tawazun counseling, initiated by Arifin and similar in concept to personcentered (Arifin, 2020; Corey, 2009; Rogers, 1942; Samsul \& Risma, 2020). The pesantren model of marriage counseling focuses on the personality of a married couple, not the problems that arise in interpersonal relationships between husband and wife (Sunarty \& Mahmud, 2016).

According to Kiai As'ad and Nyai Zai from the Pondok Pesantren Salafiyah Syafi' iyah Sukorejo, the (prospective) married couples should develop their personality that that they can do a self-control: wara', zuhud, and patient; accepting life for what it is: qona'ah, ridha, and ikhlas; and self-presentation. The personalities will radiate thinking and acting daily. They will achieve peace within the family. Sakinah will lead to the outer peace, such as the brightness of the expression on the face, and inner calm, such as being graceful (Shihab, 2006). They will reach sakinah family, dynamically calm, which refers to the peace that always develops. They sometimes experience turmoil problems within the family, yet they can deal with it. The problem is a necessity that must exist in life.

\section{Conclusion}

Pesantren has an enormous role and potential for corruption prevention. The values of pesantren associated with corruption prevention are "ngabdi" (serving others wholeheartedly). It upholds a motto, "Mondhuk entar ngabdi dan ngaji (the intention of going to pesantren is to serve and study). Pondok pesantren prioritizes the service over learning, the formation of character over science. Pesantren also avoids stealing others' belonging through a motto, "Mon ngecok jerum e pondok mon mole ka romana ngecok jheren, (if you steal a needle in pesantren, you will steal a horse once you return home)". Both values let santri accustomed to serving others and staying away from stealing others' stuff.

Meanwhile, the personalities of a husband and wife that might also support corruption prevention are capability of doing self-control: wara', zuhud, and patient; accepting life for what it is: qona'ah, ridha, and ikhlas; and self-presentation. They will be manifested in thinking and acting in everyday life. They will achieve calm and peace (sakinah) within the family. They will avoid evil actions, such as corruption. 


\section{References}

Abdusshomad. (2018). Meraih Barokah dengan Berkhidmah kepada Guru. Halal Bihalal Iksass Rayon Jember.

Abraham, J., Pane, M. M., \& Abra, A. (2014). Corruptive Tendencies , Conscientiousness, and Collectivism. Procedia - Social and Behavioral Sciences, 153, 132-147. https://doi.org/10.1016/j.sbspro.2014.10.048

Allwood, C. M. (2019). Future prospects for indigenous psychologies. Journal of Theoretical and Philosophical Psychology, 39(2), 90.

Al-Ghazali. (2000). Prinsip Dasar Agama Terjemah Kitabul Al-Arba’in fii Ushuliddin. Jakarta: Pustaka Al-Amani.

Al-Haddad, A. (2005). Terjemah an-Nashaih ad-Diniyyah wa al-Wasaya al-Iman. Yogyakarta: Mitrapustaka.

Al-Hujwiri. (2003). Kasyf al-Mahjub. Yogyakarta: Pustaka Sufi.

Al-Muhasibi. (2001). Renungan Suci Bekal Menuju Takwa (Terjemah Al-Washaya). Jakarta: Pustaka Azzam.

Al-Qusyairi. (1998). Risalah Qusyairiyah. Jakarta: Pustaka Al-Amani.

An-Najar, A. (2001). Ilmu Jiwa dalam Tasawwuf Studi Komparatif dengan Ilmu Jiwa Kontemporer. Jakarta: Pustaka Azzam.

Angraeni, S. (2016). Panduan Pelaksanaan Program Pencegahan Korupsi Berbasis Keluarga. Jakarta: KPK.

Arifin, A. S. (1992). Syair Madura (A. F. As'ad, Ed.). Situbondo: Pondok Pesantren Sukorejo.

Arifin, S. (2018). Menjadi Warga Negara Khaira Ummah Dengan Hidup Sehat Tanpa Korupsi. Jurnal Konseling Religi, 9(1), 39-60. https://doi. org/10.21043/kr.v9i1.3365

Arifin, S. (2019). A Portrait of the Sakinah Family in Manuscript Texts by Women Scholars from the Pesantren. Jurnal Harkat, 15(1), 51-59. https://doi.org/10.15408/harkat.v15i1.13441

Arifin, S. (2020). Pesantren -Based Counseling in Changing The Behaviour of The Community of Former Bajingan Being Personal Characterless 
"Pelopor." UMRAN - International Journal of Islamic and Civilizational Studies, 07(03), 59-75. https://doi.org/https://doi.org/10.11113/ umran2020.7n3.439

Arifin, S., \& Munfaridah, H. (2018). Local Wisdom Development of Pesantren Based Counseling Design with Approach Service-Learning. International Conference On University-Community Enggagement October 8-10, 2018, 3(2), 816-832. https://doi.org/10.1017/CBO9781107415324.004

Arifin, S., \& Zaini, A. (2021). Social Wellbeing and Collective Happiness (Study of "Sedekah Selamatan" on Career Development). The 3rd International Symposium on Religious Life (ISRL) 2020. https://doi.org/10.4108/eai.2$11-2020.2305073$

Arifin, S., Zaini, A., \& Wibawa, K. (2021). Strengthening Family - Based Local Cultural Values in the Conflicting Area and Marine Ecotourism of Situbondo Indonesia. Journal of Community Development Research (Humanities and Social Sciences), 14(2), 50-62. https://doi.org/10.14456/ JCDR-HS.2021.15

As'ad, Z. (1992). Zadu Az-Zaujayn. Situbondo: Salafiyah Syafi'iyah Sukorejo.

Bordens, K. S., \& Horowitz, I. A. (2008). Social Psychology. Indiana: Freeload Press.

Corey, G. (2009). Theory and Practice of Counseling and Psychotheraphy. Belmont: Thomson Higher Education.

Gadamer, G. H. (2004). Truth and Method (J. Weinsheimer \& D. G. Marshall, Eds.). News York: Continuum.

Hasan, S. A. (2003). Kharima Kiai As'ad di Mata Umat. Yogyakarta: LKIS.

Ibrahimy, A. A., \& Arifin, S. (2018). Kiai Fawaid As'ad: Kepribadian, Pemikiran, dan Perilaku Politik. Situbondo: Tanwirul Afkar.

Ibrahimy, A. A., \& Arifin, S. (2019). Risalah Hati: Trilogi Biografi Nyai Zainiyah As'ad. Situbondo: Tanwirul Afkar.

Kim, U. (2006). Indigenous and Cultural Psychology. New York,: Springer Science.

Kurniawan, R. C., \& Hermawan, D. (2009). Strategi Sosial Pencegahan Politik Uang di Indonesia. Integritas, 5(1), 29-41.

el Harakah Jurnal Budaya Islam Vol. 23 No. 1 Tahun 2021 
Liu, Q. (2016). Political connections with corrupt government bureaucrats and corporate M\&A decisions: A natural experiment from the anti-corruption cases in China. Pacific-Basin Finance Journal, 37, 52-80. https://doi.org/ https://doi.org/10.1016/j.pacfin.2016.03.003

Mapuasari, S. A., \& Mahmudah, H. (2018). Korupsi Berjamaah: Konsensus Sosial atas Gratifikasi dan Suap. Integritas, 4, 159-176.

Muzadi, H. (2006). NU Melawan Korupsi: Kajian Tafsir dan Fiqih. Jakarta. Jakarta: PBNU.

Ngendakuriyo, F., \& Zaccour, G. (2017). Should civil society organizations cooperate or compete in fighting a corrupt government? Mathematical Social Sciences, 85, 30-36. https://doi.org/https://doi.org/10.1016/j. mathsocsci.2016.11.001

Nordin, R. M., Takim, R., \& Nawawi, A. H. (2012). Transparency Initiatives ( TI ) in Construction: The Social Psychology of Human Behaviours. Procedia - Social and Behavioral Sciences, 50(July), 350-360. https://doi. org/10.1016/j.sbspro.2012.08.040

Nurinten, D., \& Mulyani, D. (2018). Kearifan Lokal Sebagai Media Pendidikan Karakter Antikorupsi pada Anak Usia Dini melalui Strategi Dongkrak. Integritas, 135-154.

Pertiwi, K. (2019). Kesenjangan dalam Wacana Antikorupsi di Indonesia: Temuan dari Literatur Studi Korupsi Kritis. Integritas, 5(2), 133-150.

Pramanta, F. D., Hasanah, U. U., \& Kurniawan, R. (2016). Pengembangan Buku Cerita Interaktif Antikorupsi Berbasis Teknologi Augmented Reality. Integritas, 4, 57-76.

Riyadi, A. (2013). Bimbingan Konseling Keluarga: Dakwah dalam Membentuk Keluarga Sakinah. Yogyakarta: Ombak.

Rogers, C. R. (1942). Counseling and Psychotherapy Newer Concepts in Practice. Cambridge: The Ribersibe Press.

Sahama, S., Shofia, A., Reiza, M., \& Riyono, B. (2019). Corruption in Indonesia : An Investigation From Mental Health, Spirituality, and Leadership Perspectives. Malaysian Journal of Medicine and Health Sciences, 15(April), 45-53.

el Harakah Jurnal Budaya Islam Vol. 23 No. 1 Tahun 2021 
Samsul, A., \& Risma, A. F. (2020). The Model of Development Therapeutic Speech in the Digital Era: A Study of "Interpretation of Al-Mishbah" for Cyber-Counseling Services. Proceedings of the 19th Annual International Conference on Islamic Studies, AICIS 2019, 1-4 October 2019, Jakarta, Indonesia. https://doi.org/10.4108/eai.1-10-2019.2291647

Setjitden Pendidikan Islam Kemenag RI. (2010). Statistik Pendidikan Tahun 2009/2010. http://pendis.kemenag.go.id/file/dokumen/ bukusaku01.pdf

Shafii, M. (2004). Psikoanalisis dan Sufisme (Freedom from the Self: Sufisme, Meditation, and Psychotherapy). Yogyakarta: Campus Press.

Shelley E. Taylor, Peplau, L. A., \& Sears, D. O. (2003). Social Psychology. New Jersey: Pearson.

Shihab, Q. (2006). Perempuan: dari Cinta sampai Seks, dari Nikah Mut'ah sampai Nikah Sunnah, dari Bias Lama sampai Bias Baru. Jakarta: Lentera Hati.

Shurkina, E. Y., Sarkin, A. V, Averyanov, B. A., \& Svirina, A. A. (2013). Entrepreneurial development in a corrupted environment. Procedia Economics and Finance, 5(903), 73-82. https://doi.org/10.1016/S22125671(13)00012-9

Suhrawardi, S. H. (1998). Awarif al-Ma'arif: Sebuah Buku Daras Klasik Tasawuf. Bandung: Pustaka Hidayah.

Sunarty, K., \& M, A. (2016). Konseling Perkawinan dan Keluarga. Makasar: UNM.

Wahid, A. (2007). Menggerakkan Tradisi: Esai-Esai Pesantren. Yogyakarta: LkiS.

Zaini, A., \& Arifin, S. (2018). Environmentally Sound Empowerment Da'wah For Conflict Areas of Baluran Forest Situbondo. International Conference on University-Community Enggagement October 8-10, 2018, 40-51. Malang: UIN Maliki Press. 